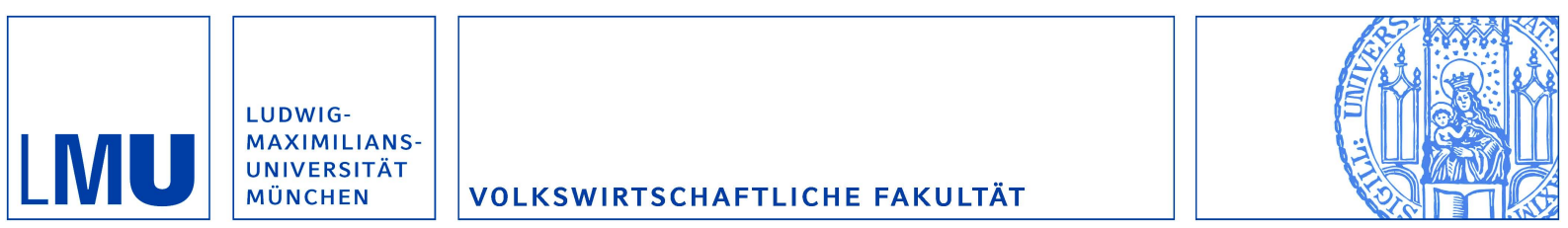

Haufler, Andreas und Lülfesmann, Christoph:

Reforming an Asymmetric Union: On the Virtues of Dual Tier Capital Taxation

Munich Discussion Paper No. 2013-1

Department of Economics

University of Munich

Volkswirtschaftliche Fakultät

Ludwig-Maximilians-Universität München

Online at https://doi.org/10.5282/ubm/epub. 14358 


\title{
Reforming an Asymmetric Union: On the Virtues of Dual Tier Capital Taxation *
}

\author{
Andreas Haufler ${ }^{\dagger}$ \\ University of Munich and CESifo
}

Christoph Lülfesmann $\ddagger$

Simon Fraser University and CESifo

\section{January 2013}

\begin{abstract}
The tax competition for mobile capital, in particular the reluctance of small countries to agree on measures of tax coordination, has ongoing political and economic fallouts within Europe. We analyse the effects of introducing a two tier structure of capital taxation, where the asymmetric member states of a union choose a common, federal tax rate in the first stage, and then non-cooperatively set local tax rates in the second stage. We show that this mechanism effectively reduces competition for mobile capital between the members of the union. Moreover, it distributes the gains across the heterogeneous states in a way that yields a strict Pareto improvement over a one tier system of purely local tax choices. Finally, we present simulation results, and show that a dual structure of capital taxation has advantages even when side payments are feasible.
\end{abstract}

Keywords: capital tax competition, dual tier taxation, international unions JEL Classification: H25, H77, H87

*Paper presented at the Annual Congresses of the International Institute of Public Finance in Dresden and of the German Economic Association in Göttingen. We thank conference participants, in particular David Agrawal, Thiess Büttner, Jim Hines and Dominika Langenmayr for helpful comments. This paper was started when the first author visited Simon Fraser University. He wishes to thank the Department of Economics for its hospitality. Financial support by SSHRC is gratefully acknowledged.

${ }^{\dagger}$ Seminar for Economic Policy, Akademiestr. 1/II, D-80799 Munich, Germany. Phone: +49-89-21803858, e-mail: Andreas.Haufler@lrz.uni-muenchen.de

${ }^{\ddagger}$ Department of Economics, Simon Fraser University, 8888 University Drive, Burnaby BC, V5A 1S6, Canada. Phone: +1-(778)-782 8504, e-mail: cluelfes@sfu.ca. 


\section{Introduction}

During the last decades, foreign direct investment (FDI) has increased rapidly in all parts of the world. Among the different regions, Europe is by far the most important source and destination of FDI, accounting for roughly half of all worldwide inflows and outflows (Barba Navaretti and Venables, 2004). Moreover, the growth of FDI has also been stronger in Europe than elsewhere, as a result of deepening economic integration in the European Union (EU). With capital mobility being particularly high in Europe, tax competition can also be expected to be more aggressive. And indeed, recent empirical work confirms the existence of strategic interaction in corporate tax setting among OECD countries in general, but in particular among the member states of the EU (Devereux et al., 2008; Cassette and Paty, 2008). ${ }^{1}$

The implication of tax competition may be very different across countries, however. Table 1 shows how tax competition has affected corporate tax rates and tax revenues in the EU-15 member states, differentiating between small and large countries. ${ }^{2}$ Since the mid-1980s, corporate tax rates have fallen strongly in almost all EU-15 member states, but they fell even more, on average, in the small countries. At the same time small countries fared better with respect to corporate tax revenues, which increased substantially, as a share of GDP, until the mid-2000s (before the onset of the financial crisis). An extreme example is Ireland, which has managed to secure a large increase in its corporate tax revenues with a statutory tax rate of only $12.5 \%$. But other countries, notably in Scandinavia, have also been able to substantially raise their corporate tax revenues despite - or perhaps because of - dramatic cuts in corporate tax rates.

During the same time, corporate tax revenues as a share of GDP stagnated, on average, in the five large EU members, and they actually fell in several of them. Finally, Table 1 also includes several large non-EU countries for comparison. These countries have maintained higher tax rates and secured larger increases in corporate tax revenues than is true for the large EU countries. This may be viewed as an indication that non-EU countries were less exposed to the forces of tax competition than EU members.

\footnotetext{
${ }^{1}$ In the study of Devereux et al. (2008), 15 of the 21 countries in the sample are members of the EU. Hence this study is to a large extent a study on strategic tax interaction in Europe.

${ }^{2}$ An important factor not covered in Table 1 is tax competition from the new EU member states in Central and Eastern Europe. On average, statutory corporate tax rates in these countries were around $20 \%$ in 2012, and thus even lower than in the small EU-15 states.
} 
Table 1: Corporate tax rates and tax revenues in OECD countries

\begin{tabular}{|c|c|c|c|c|c|}
\hline & \multicolumn{3}{|c|}{$\begin{array}{l}\text { statutory } \\
\text { tax rate }\end{array}$} & \multicolumn{2}{|c|}{$\begin{array}{c}\text { corporate } \\
\text { tax revenue }\end{array}$} \\
\hline & 1985 & 2005 & 2012 & 1985 & 2005 \\
\hline \multicolumn{6}{|c|}{ large EU-15 countries (population $>20$ million) } \\
\hline France & 50 & 34 & 34 & 1.9 & 2.4 \\
\hline Germany & 63 & 38 & 30 & 2.2 & 1.8 \\
\hline Italy & 46 & 37 & 27 & 3.1 & 2.8 \\
\hline Spain & 35 & 35 & 30 & 1.4 & 3.9 \\
\hline United Kingdom & 40 & 30 & 24 & 4.7 & 3.3 \\
\hline$\varnothing$ large EU-15 countries ${ }^{c}$ & 46.8 & 34.8 & 29.0 & 2.7 & 2.8 \\
\hline \multicolumn{6}{|c|}{ small EU-15 countries (population $<20$ million) } \\
\hline Austria & 61 & 25 & 25 & 1.4 & 2.2 \\
\hline Belgium & 45 & 34 & 34 & 2.2 & 3.3 \\
\hline Denmark & 50 & 28 & 25 & 2.2 & 3.9 \\
\hline Finland & 60 & 26 & 25 & 1.4 & 3.3 \\
\hline Greece & 44 & 32 & 20 & 0.7 & 3.3 \\
\hline Ireland & 10 & 13 & 13 & 1.1 & 3.4 \\
\hline Luxembourg & 40 & 30 & 29 & 7.0 & 5.8 \\
\hline Netherlands & 43 & 32 & 25 & 3.0 & 3.8 \\
\hline Portugal & 55 & 28 & 32 & $2.1^{d}$ & 2.7 \\
\hline Sweden & 60 & 28 & 26 & 1.7 & 3.7 \\
\hline$\varnothing$ small EU-15 countries ${ }^{c}$ & 46.8 & 27.6 & 25.4 & 2.3 & 3.5 \\
\hline$\varnothing$ ØEU-15 countries ${ }^{c}$ & 46.8 & 30.0 & 26.6 & 2.4 & 3.3 \\
\hline \multicolumn{6}{|c|}{ large non-EU countries (population $>20$ million) } \\
\hline Australia & 50 & 30 & 30 & 2.6 & 5.8 \\
\hline Canada & 45 & 34 & 26 & 2.7 & 3.5 \\
\hline Japan & 56 & 40 & 40 & 5.7 & 4.3 \\
\hline United States & 50 & 39 & 39 & 1.9 & 3.2 \\
\hline$\varnothing$ large non-EU countries ${ }^{c}$ & 50.2 & 35.8 & 33.8 & 3.2 & 4.2 \\
\hline
\end{tabular}

${ }^{a}$ including state and local taxes

${ }^{b}$ in $\%$ of GDP

${ }^{c}$ unweighted average

d 1990

Sources: OECD (2011), Table 11 http://dx.doi.org/10.1787/888932508870

OECD Tax Database. http://www.oecd.org/tax/taxpolicyanalysis/oecdtaxdatabase.htm 
As indicated by these developments, the most important obstacle to effectively constrain corporate tax competition within a union appears to be the existence of winners (and losers) under the existing system. Low-tax countries, which benefit from an inflow of capital, are unwilling to give up this advantage. In an institutional setting where measures of tax coordination require unanimity among all member states (as is the case in the EU), such conflicts of interest have the potential to block reforms of the status quo, unless side payments can be made to the low-tax countries in exchange for their consent to a reform. Making such side payments is difficult, however, because governments often face political resistance against monetary payments in exchange for political concessions from the other side. Moreover, negotiations that involve side payments are typically subject to strategic behavior on the part of the involved parties, resulting in substantial delays for policy reform (Harstad, 2007). ${ }^{3}$

These political economy issues are likely to explain why no attempt for tax rate harmonisation has been made in the European Union for the last twenty years, since the failed attempt of the Ruding Committee (1992) to establish a harmonised minimum corporate tax rate of $30 \%$ among EU member states. Instead, the EU has focused on other areas of corporate taxation, such as the elimination of preferential tax regimes ${ }^{4}$, or the proposal to establish a common consolidated corporate tax base for multinational companies (European Commission, 2011). Under both of these coordination measures, member states remain completely free to set (non-discriminatory) corporate tax rates in a non-cooperative way. Several analyses have concluded that these measures will not reduce the incentives to engage in tax competition, and they may even offer further arguments for tax rate harmonisation (Keen, 2001; Bettendorf et al., 2010).

Against this policy background, we explore an economic model where 'small' members of the federation are the winners of tax competition, and have no incentive to agree on a common federal tax on capital. To remedy this situation, the paper proposes a dual

\footnotetext{
${ }^{3} \mathrm{An}$ example of such delays is the EU savings tax directive, which has introduced a system of information exchange to reduce the evasion of interest income tax. The directive was proposed in 1998 but it only came into effect in 2005. Even then, several small countries that had objected to the coordination measure (Austria, Belgium and Luxembourg) were allowed to gradually phase in the reform over several years, and to keep part of the interest withholding taxes collected from foreigners in the transition phase.

${ }^{4}$ See Nicodème (2009) for an account of the policy developments in this area, and for a survey of the related literature.
} 
structure of capital taxation where the asymmetric member states of a union agree on some uniform, federal tax rate in the first stage, and then non-cooperatively set local tax rates in the second stage. We show that such a simple mechanism succeeds in reducing tax competition among the members of the union. At the same time, it distributes the gains from partial coordination across members in a way that yields a strict Pareto improvement over a one tier system of purely local capital tax competition, without requiring an explicit compensation mechanism. This last property makes our analysis especially relevant for a union of countries that starts out with weak taxing powers at the federal level, as is true, for example, for the European Union.

The beneficial effects of a dual capital tax arise because this structure combines the advantages of a uniform federal tax with the advantages that decentral taxation rights provide to small members in the federation. The federal tax raises aggregate tax revenues within the union when the intra-union competition for mobile capital is the binding constraint for tax policy. In the dual tax equilibrium, this positive revenue effect is achieved by distributing the proceeds of the federal tax in proportion to each country's capital endowment. ${ }^{5}$ At the same time, permitting each country to levy additional local taxes in a non-cooperative way preserves the tax advantage that small countries enjoyed prior to the reform. While this tax advantage is shown to be less pronounced than in a purely decentralised system, the continued right to tax locally ensures tax coordination to become agreeable for all asymmetric member states within the union.

In the tax optimum that results under such a dual capital tax, the sum of federal and local tax rates will be constrained by the worldwide competition for mobile capital. Given the asymmetric local taxes, this constraint will be binding only for the large, high-tax countries. As a result the tax gap narrows in equilibrium, relative to a one tier capital structure, leading to greater production efficiency in the union. At the same time, the federal tax will never be chosen so high that there is no room for additional local taxes: if the federal tax rate becomes 'too high', the local tax differential shrinks to a level at which small countries would refuse to participate in the mechanism. Hence the equilibrium tax structure will always feature positive federal and local tax rates. Finally, we show that this basic argument for a two tier tax structure is maintained

\footnotetext{
${ }^{5}$ In technical terms, the distribution of federal tax revenues follows the residence principle, whereas local taxes are levied under the origin principle.
} 
when costly side payments are allowed for.

A critical assumption underlying our analysis is that intra-union tax competition is stronger than the simultaneous tax competition between union members and the rest of the world. There are, however, good theoretical and empirical reasons for this presumption. From a theoretical perspective, tax harmonisation within a subgroup of countries is welfare improving whenever the union is large in the world economy (Konrad and Schjelderup, 1999; Sørensen, 2004; Conconi et al., 2008). Moreover, tax competition within the union can be expected to be particularly severe, due to otherwise similar location conditions that exist in an integrated market. Any location rent that arises from the existence of a common market can thus be taxed by the union as a whole, but only if competition between its members is prevented (Keen, 1993; Haufler and Wooton, 2006). Empirically, several studies suggest that foreign direct investment responds more sensitively to international tax differentials within an economic union (Devereux and Griffith, 1998; Grubert and Mutti, 2000), and that strategic tax interaction is stronger between the members of a union than with outside countries (Davies and Voget, 2011). ${ }^{6}$

Our paper builds on the basic model of asymmetric tax competition in a one-tier setting by Bucovetsky (1991) and Wilson (1991), which we extend to allow for multiple jurisdictions of each type. It is also related to the literature on tax competition in federal states, but there are important differences. One often studied issue in the federalism literature is that different levels of government simultaneously impose taxes on the same tax base. This gives rise to vertical fiscal externalities and leads to the possibility of excessive taxation within a federation (Wrede, 2000; Keen and Kotsogiannis, 2002). In contrast, we focus on a setting where horizontal externalities dominate in tax competition. Another important element of federations is the existence of fiscal equalisation schemes. As the literature has shown, this may reduce tax competition by equalising either tax revenues or tax bases among the lower levels of government (Köthenbürger, 2002, Hindriks et al., 2008). In our model, the dual tax structure also reduces effective tax competition, but the underlying mechanism does not require explicit or implicit transfers within the federation.

\footnotetext{
${ }^{6}$ An additional factor that affects tax competition within a union, but is not covered in our analysis, is labour mobility. See Kessler et al. (2002) and, more recently, Wildasin (2011) for tax competition models that include both labour and capital mobility.
} 
Our paper can also be linked to the general literature on fiscal federalism (Oates, 1972, Lockwood, 2002; Besley and Coate, 2003; Janeba and Wilson, 2011), where a central issue is the choice between uniformity and differentiation of policies within a federation. Alesina et al. (2005) analyse the federal and local provision of public goods in the presence of interregional benefit spillovers. They find that dual provision of this sort raises welfare for a majority of regions and citizens. Regarding its focus on taxation issues, our paper is closer to Keen and Smith (1996), who propose a two tier structure for the European value-added tax, with a harmonised federal rate and differentiated local tax rates. Their case for a dual system of value-added taxation is primarily based on administrative concerns and the compatibility with the EU internal market, however, rather than on mitigating tax competition as in the present paper.

This paper proceeds as follows. In Section 2 we set out the basic one tier model of capital tax competition as a benchmark. Section 3 analyses the dual model of capital taxation, solving first for the non-cooperative local tax rates in the second stage and then for the cooperative choice of the federal tax rate in the first stage of the game. Section 4 introduces the possibility of side payments and discusses different modifications of our basic model. Section 5 concludes.

\section{One Tier Capital Taxation}

\subsection{Asymmetric tax competition}

We set up a workhorse model of capital tax competition within a union of asymmetric countries. Our model extends the analysis in Bucovetsky (1991) and Wilson (1991), where two countries of different size compete against each other, to allow for a variable number of both small and large countries. This implies that in our model there will be tax competition within the groups of small and large countries, as well as competition between countries of different size.

We index the two groups of countries, large and small, by $L$ and $S$, respectively. There are $n_{L}$ identical large countries and $n_{S}$ small countries. Small and large countries have the same per capita endowment of capital, but differ in their absolute sizes. The size parameter of a large country, which reflects its population size, is $\alpha_{L}$, whereas the size of each small country is $\alpha_{S}$, with $\alpha_{L}>\alpha_{S}$. The total population in the union, $N$, is 
therefore given as

$$
n_{S} \alpha_{S}+n_{L} \alpha_{L}=N
$$

Each worker in the union has the same per capita capital endowment $\bar{k}$. The total capital stock in the union is therefore $K=N \bar{k}$. Capital is freely mobile across jurisdictions, implying that the per capita capital stock employed in each country, $k_{i}$, may differ from this country's capital endowment. Each country $i$ of type $j=S, L$ produces output using a quadratic per capita production function $f\left(k_{i}\right)=k_{i}\left(a-b k_{i} / 2\right)$, with $a$ and $b$ being positive parameters. Capital market clearing implies

$$
n_{S} \beta_{S} k_{S}+n_{L} \beta_{L} k_{L}=\bar{k},
$$

with $\beta_{i}=\alpha_{i} / N \in(0,1)$ indicating the relative size of country $i$ within the federation.

Due to perfect capital mobility, the net return to capital must be identical everywhere. We introduce local capital taxes $t_{i}$ that are levied under the source principle. ${ }^{7}$ The net return to capital $r$ then equals

$$
r=a-b k_{i}-t_{i}>0 \quad \forall \quad i
$$

which we assume to be positive in all countries. ${ }^{8}$

In what follows, it will be useful to define average tax rates on a per capita basis. Specifically, define the federation wide average (per capita) tax rate in all countries $h$ other than $i$ as

$$
\bar{t}_{-i}=\frac{1}{N-\alpha_{i}} \sum_{h \neq i} \alpha_{h} t_{h} .
$$

Then the federation wide average tax rate can be written as

$$
\bar{t}=\left[\bar{t}_{-i}+\frac{\alpha_{i} t_{i}}{N-\alpha_{i}}\right] \frac{N-\alpha_{i}}{N}=\beta_{i} t_{i}+\left(1-\beta_{i}\right) \bar{t}_{-i} .
$$

Invoking the arbitrage condition (3), country $i$ 's capital stock, as a function of its own tax rate $t_{i}$ and the average tax rate in the rest of the union, can now be written as ${ }^{9}$

$$
k_{i}^{*}\left(t_{i}, \bar{t}_{-i}\right)=\bar{k}+\frac{\left(1-\beta_{i}\right)\left(\bar{t}_{-i}-t_{i}\right)}{b} .
$$

${ }^{7}$ The source principle implies that capital is taxed in the country where it is employed, whereas the country in which the capital owner resides exempts this income from tax. For the corporate tax, this scheme is employed by almost all OECD countries, with the notable exception of the United States.

${ }^{8}$ See Bucovetsky (1991, sec. 4) for an analysis of the (mild) conditions that rule out Nash equilibria in an 'excess supply' regime with a zero return to capital.

${ }^{9}$ Multiplying the arbitrage condition (3) with the weights $n_{S} \beta_{S}$ and $n_{L} \beta_{L}$, respectively, and summing over these two terms gives $a-b \bar{k}-\bar{t}=r$. Subtracting this from (3) and using (4) yields (5). 
Equation (5) immediately reveals that $k_{i}^{*}$ is decreasing in $t_{i}$ and increasing in the average of tax rates in all other countries. ${ }^{10}$ Also, the lower is country $i$ 's weight $\beta_{i}$, the more does its per capita capital endowment vary in the tax difference $\left(\bar{t}_{-i}-t_{i}\right)$.

Governments in each country $i$ are assumed to maximise local per capita tax revenues. ${ }^{11}$ These are

$$
R_{i}\left(t_{i}, \bar{t}_{-i}\right)=t_{i} k_{i}^{*}=t_{i}\left[\bar{k}+\frac{\left(1-\beta_{i}\right)\left(\bar{t}_{-i}-t_{i}\right)}{b}\right] \quad \forall i .
$$

We are now prepared to explore the optimal tax policies in each country. Taxes $t_{i}$ are set non-cooperatively in order to maximise $R_{i}$. For a given vector $t_{-i}$, the first-order condition to (6) yields country $i$ 's reaction function:

$$
t_{i}^{*}\left(t_{-i}\right)=\frac{b \bar{k}}{2\left(1-\beta_{i}\right)}+\frac{\bar{t}_{-i}}{2}
$$

In a symmetric equilibrium, all countries $i$ of type $j$ choose an identical tax rate. As a result, average equilibrium tax rates in countries other than $i$ (with country $i$ being of type $j$ ) satisfy

$$
\bar{t}_{-i}=\frac{\left(n_{j}-1\right) \alpha_{j} t_{j}+n_{m} \alpha_{m} t_{m}}{N-\alpha_{m}} \quad \forall j \neq m .
$$

Using this in (7), equilibrium taxes for each country type $j=S, L$ are given by

$$
t_{j}^{*}\left(t_{m}\right)=\frac{b \bar{k} N+n_{m} \alpha_{m} t_{m}}{2 N-\alpha_{j}\left(n_{j}+1\right)} \quad \forall j \neq m
$$

Equilibrium taxes are now easily computed as

$$
t_{j}^{*}=\frac{b \bar{k} N\left(2 N-\alpha_{m}\right)}{\rho} \quad \forall j \neq m,
$$

where

$$
\rho=\left[2 N-\alpha_{S}\left(n_{S}+1\right)\right]\left[2 N-\alpha_{L}\left(n_{L}+1\right)\right]-n_{S} n_{L} \alpha_{S} \alpha_{L}
$$

\footnotetext{
${ }^{10}$ Specifically, notice that country $i$ 's capital stock only depends on an aggregate of the taxes in other countries, that is, the composition of those tax rates does not matter in our linear model.

${ }^{11} \mathrm{We}$ assume tax revenue maximisation primarily for its expositional simplicity. All qualitative results from our analysis would carry over to a more general setting where governments maximise the utility of a representative citizen and the marginal rate of substitution between private and public consumption is constant. The core implication in either case is that tax rates are strategic complements and best responses are upward sloping (see Kanbur and Keen, 1993). This last result also corresponds to the existing empirical evidence (Devereux et al., 2008; Davies and Voget, 2011).
} 
In a final step, we substitute (10) in (6) to get per capita tax revenues in each country type in the non-cooperative tax equilibrium:

$$
R_{S}^{*}=\frac{b \bar{k}^{2} N\left(2 N-\alpha_{L}\right)^{2}\left(N-\alpha_{S}\right)}{\rho^{2}}, \quad R_{L}^{*}=\frac{b \bar{k}^{2} N\left(2 N-\alpha_{S}\right)^{2}\left(N-\alpha_{L}\right)}{\rho^{2}} .
$$

We can now state:

Proposition 1 In the one tier model of asymmetric capital tax competition, small countries choose taxes more aggressively than large countries, $t_{S}^{*}<t_{L}^{*}$, and attract more capital in per capita terms, $k_{S}^{*}>k_{L}^{*}$, for any $\left(\alpha_{L}, \alpha_{S}, n_{S}, n_{L}\right)$. Moreover, equilibrium per capita tax revenues in each small country, $R_{S}^{*}$, exceed those in the large countries.

Proof: The first result follows directly from (10) and $\alpha_{S}<\alpha_{L}$. The second result follows from (5) and the symmetric responses of all countries of the same type. For the last result, the difference in per capita tax revenues in (12) can be transformed to

$$
R_{S}^{*}-R_{L}^{*}=\frac{b \bar{k}^{2} N}{\rho^{2}}\left(\alpha_{L}-\alpha_{S}\right)\left[\left(N-\alpha_{S}\right) \alpha_{L}+N \alpha_{S}\right]>0
$$

Proposition 1 extends previous findings in the literature on asymmetric tax competition (Bucovetsky, 1991; Wilson, 1991). Their basic insight that small countries underbid their larger neighbours carries over to a setting where tax competition occurs not only between large and small countries, but also within each size group. Capital arbitrage then implies $k_{S}^{*}>\bar{k}>k_{L}^{*}$. By setting a lower tax rate than their larger neighbours, each of the small countries attracts a larger per capita share of mobile capital in equilibrium. A simple revealed preference argument then shows that this strategy must yield larger tax revenues: a small country could simply replicate the per capita revenues of a large country by raising its tax to $t_{L}^{*}$. It will underbid only if this raises its revenues.

Proposition 1 also corresponds closely to the empirical evidence for the EU-15 countries. As Table 1 shows, the small union members have lower corporate tax rates, on average, than the larger members, even though they started from very similar tax rates in 1985 (before tax competition became a prominent issue). At the same time, per capita corporate tax revenues of the small countries substantially exceed those of the large EU members, on average, suggesting that small countries have been able to attract internationally mobile profit tax bases from their larger EU neighbours. ${ }^{12}$

\footnotetext{
${ }^{12}$ For a detailed empirical evaluation of the growth-enhancing role of low capital taxes in Ireland, see Romalis (2007).
} 


\subsection{Tax harmonisation}

We now assume that governments in all countries have the option to harmonise their tax policies, by raising capital taxes $t_{i}$ up to a common, exogenous level $t^{\text {max }}>0 .{ }^{13}$ The most straightforward interpretation of $t^{\max }$ is as being the maximum tax rate that is sustainable in the competition for mobile capital with third countries, where this outside tax competition is taken as exogenous in our analysis. To give a specific example, assume that moving capital from a union member to an outside country involves relocation costs $\mu$ per unit of capital, while the tax rate in the rest of the world is $t^{W}$. Then the maximum feasible tax rate that prevents the relocation of capital to third countries is $t^{\max }=\mu+t^{W}$. At the same time, all capital will leave the union, and tax revenues in each member state will be zero, once the threshold tax rate $t^{\max }$ is surpassed. Assuming that capital flows to third countries take this 'all-or-nothing' form is a simple way to capture tax competition with the rest of the world, while accounting for the empirical fact that this competition is less aggressive than tax competition within the union (see Davies and Voget, 2011, for empirical evidence). In Section 4.2 we extend our basic model to allow for continuous capital flows to third countries.

In the following, we impose two natural assumptions on $t^{\max }$. First, we assume the maximum tax rate to lie below the expropriation level so that the net return to capital in (3) remains positive even when all countries set $t_{i}=t^{\max }$. Second, $t^{\max }>t_{L}^{*}$ so that the equilibrium tax rates in (10) represent an interior Nash equilibrium, even with the additional constraint $t_{i} \leq t^{\max }$ for each country $i$.

In this setting, it is obvious that aggregate tax revenue in the union would be maximised if each country chooses the tax rate $t^{\max }$. On the other hand, coordinated action in the absence of side payments does not necessarily constitute a Pareto improvement. This is true in particular for the small countries, who undercut the large countries' capital tax rates in the non-cooperative tax equilibrium and secure higher per capita tax

\footnotetext{
${ }^{13}$ Our one tier model thus adopts a strict view of tax harmonisation, requiring that tax rates are equalised in all countries. An alternative sometimes analysed in the literature is the setting of a minimum tax rate. As the literature has shown, however, minimum tax rates do not eliminate strategic interactions between countries and results depend strongly on whether tax competition is analysed in a Nash or in a Stackelberg model, and whether minimum tax rates are binding or not. See Kanbur and Keen (1993), Wang (1999) and Konrad (2009). In the present analysis we want to avoid these complications, in order to have a clear reference point for the dual tier structure analysed below.
} 
revenues (Proposition 1). Let $R_{i}(t)$ denote country $i$ 's tax revenue under a cooperative solution with a common tax rate $t$ and compare this with each country's revenue under decentralised tax competition [eq. (12)]. Then, a coordinated outcome that is unanimously approved by all countries cannot be achieved under a one tier structure of capital taxation iff the following condition holds:

$$
R_{S}^{*}>R_{S}\left(t^{\max }\right)=t^{\max } \bar{k}
$$

To understand this condition, notice first that for each country the cooperative revenue $R_{i}(t)$ increases in $t$. Hence, the case for harmonisation is most compelling when countries agree on the maximum tax $t^{\max }$. Moreover, the large country is always in favour of tax coordination: tax harmonisation not only helps it to raise its tax rate, but it also gains from a larger (per capita) capital tax base, relative to the non-cooperative equilibrium. Hence, $R_{L}^{*}>R_{L}\left(t^{\max }\right)$ will never be binding. Small countries, in contrast, attract a disproportional share of total capital in the non-cooperative equilibrium. When they agree to harmonise taxes, they will therefore suffer from a reduction in per capita capital supply and a corresponding decrease in government revenues that might well offset the positive effect of a larger common tax rate. Hence it is the small countries who decide whether cooperation is accomplished or not. This gives

Corollary 1: Tax harmonisation fails if and only if small countries oppose it.

The remainder of the paper focuses on an economic scenario where condition (13) is fulfilled and hence tax coordination cannot be achieved under a one tier structure of capital taxation. The next section introduces a dual tier system and shows that in such an institutional setting at least partial cooperation is always feasible, even if side payments are ruled out.

\section{Dual Tier Capital Taxation}

We now explore a scenario that combines capital taxation at the federal level with subsequent taxation at the decentralised level of government. The key element of this system is that in a stage 1, all countries can agree on a uniform federal capital tax $T$. This federal capital tax is levied on the entire capital stock in the union, and redistributed to the individual countries in proportion to their capital endowments. In 
our framework, where these endowments are per capita the same in all countries, this corresponds to equal per capita remittances. ${ }^{14}$

Such a tax has a variety of natural interpretations. First, it can literally be interpreted as a tax on capital that is refunded to all countries in proportion to their size, or capital endowment. Alternatively, federal tax revenues finance projects that benefit each country in proportion to its size, thus allowing each country to reduce their local expenditures on these projects. A third interpretation with particular relevance to a EU context is that the own resources of the federal government are used to reduce the contributions of member states, again in proportion to their size. ${ }^{15}$

In our basic model we exclude side payments so that any successful agreement on $T$ must raise the overall tax revenues of each member state. We assume that the outcome of negotiations is such that countries split the negotiation surplus over the noncooperative tax equilibrium in a Nash bargaining fashion. Specifically, small countries are characterised by a collective bargaining parameter $\gamma \in[0,1]$, whereas the bargaining power of the large countries is $(1-\gamma)$. While we can remain agnostic regarding the size of $\gamma$, it might be positively linked to the share of small countries in the union, $n_{S} /\left(n_{S}+n_{L}\right) \cdot{ }^{16}$

Subsequently, in a stage 2, each country $j$ sets an additional local capital tax $t_{j}$. As in the one tier workhorse model of Section 2, these taxes are chosen in a non-cooperative way. For the same reasons as we have given in the one tier model above, the total taxes $T+t_{j}$ per unit in country $j$ cannot exceed the exogenous level $T^{\max }$, where $T^{\max }=t^{\max }$ is identical to the maximum (local) tax rate in Section 2. Again, we focus on equilibria where all countries of the same size choose the same tax rate in equilibrium.

Using subgame perfection as the appropriate equilibrium concept, the analysis starts

\footnotetext{
${ }^{14}$ In our basic model where no capital flows out of the union, it is irrelevant whether the federal tax is collected in the country where the capital is employed (source principle), or in the country where the capital owner resides (residence principle). Most of the literature argues that it is easier to collect taxes in the source country. Note also that assuming a fixed union-wide capital stock rules out vertical tax externalities, as analysed in the fiscal federalism literature (Keen and Kotsogiannis, 2002).

${ }^{15}$ Results differ when federal tax receipts are instead redistributed to union members in proportion to the capital stock they employ in equilibrium. See Section 4.4 for further discussion.

${ }^{16}$ The specific institutional structure within the federation will clearly also matter for the size of $\gamma$. An important issue is, for example, to what extent the representation of small versus large countries in the union's governing bodies reflects relative population size.
} 
with the second stage of the game. Notice that any federal tax $T$ implemented in stage 1 does not bias the distribution of capital between countries. Hence, federal taxes do not alter each country's incentive to attract the mobile factor, and $T$ affects decisions in stage 2 only through its impact on feasible local tax rates. In particular, when setting its local tax rate, each country must satisfy the constraint $t_{j} \leq T^{\max }-T$, a constraint which becomes tighter the larger $T$ is.

\subsection{Stage 2: Local tax equilibrium}

The analysis starts with the stage 2 tax decisions of local governments for varying levels of the federal tax $T$, as agreed upon in stage 1 . To do so, it is convenient to divide the entire range of federal taxes $\left[0, T^{\max }\right]$ into various regions.

Let us begin with Regime I where $T \in\left[0, T_{1}\right]$, and an upper boundary defined by

$$
T_{1}=T^{\max }-t_{L}^{*}
$$

Over this range of federal taxes, the equilibrium local tax rates $\left(t_{L}^{*}, t_{S}^{*}\right)$ in the standard model remain feasible. ${ }^{17}$ Federal taxes generate lump sum revenues and thus leave each country's reaction function in the relevant range $t_{j} \leq t_{j}^{*}$ unaltered. As a consequence, the equilibrium in local taxes does not change and $\left(t_{L}^{*}, t_{S}^{*}\right)$ remains the unique equilibrium. Within Regime I, the only impact of federal capital taxes is thus to raise all countries' revenues by the same per capita amount $T \bar{k}$, which is certainly welcomed by all local governments. Small countries thus continue to have higher per capita tax revenues than large countries in this regime.

Consider now Regime II, characterised by the interval of tax rates $T \in\left[T_{1}, T_{2}\right]$. Defining $t_{L}^{* *}=T^{\text {max }}-T$, the tax rate $t_{S}^{* *}(T)=t_{S}^{*}\left(t_{L}^{* *}\right)$ is the best response for a country $S$ when $L$ chooses the largest admissible tax. The upper boundary of Regime II is now defined as

$$
T_{2}=T^{\max }-t_{S}^{* *}\left(T_{2}\right) .
$$

For federal taxes larger than $T_{1}$, the constraint not to exceed $T^{\max }$ becomes binding for the large countries, which impose the higher tax rate under the one tier structure of capital taxation (as well as in Regime I). A local rate $t_{L}^{*}$ ceases to be feasible because for any $T>T_{1}$, total taxes would violate the constraint $T+t_{L}^{*} \leq T^{\max }$. Conversely,

\footnotetext{
${ }^{17}$ Recall $t_{S}^{*}<t_{L}^{*}$ and notice from (14) that for $T<T_{1}$, combined taxes $T+t_{L}^{*}$ are less than $T^{\text {max }}$.
} 
provided that large countries opt for $t_{L}^{* *}$, the maximum-tax constraint for an $S$ country is slack until $T$ hits the interval's upper boundary, $T_{2}$. To understand this, notice that $t_{S}^{* *}(T)$ is the small countries' unconstrained best response to the large countries' boundary tax choice $t_{L}^{* *}$. This best response is decreasing in $T$ because the reaction function is upward sloping and a larger $T$ reduces $t_{L}^{* *}$. As long as $t_{S}^{* *}+T \leq T^{\text {max }}$, that is, as long as $T<T_{2}$, the maximum-tax constraint does not bind for small countries.

What are the equilibrium local tax rates in Regime II? Suppose first that $S$ countries do not adjust their tax rate and still set $t_{S}=t_{S}^{*}$. Then, $L$ countries in response adopt $t_{L}^{* *}=T^{\max }-T$ : large countries' revenues are increasing for any $t_{L}<t_{L}^{*}$ so that their best response is the largest admissible tax rate. At the same time, the best response of $S$ countries to $t_{L}^{* *}$ is some $t_{S}^{* *}$ strictly smaller than $t_{S}^{*}$ because their own reaction function is upward sloping in $t_{L}$. Using (9), one can now easily characterise the unique equilibrium $\left[t_{S}^{* *}(T), t_{L}^{* *}(T)\right]$ as

$$
\begin{gathered}
t_{S}^{* *}(T)=\frac{b \bar{k} N}{\left[2 N-\alpha_{S}\left(n_{S}+1\right)\right]}+\frac{\left(N-n_{S} \alpha_{S}\right)}{\left[2 N-\alpha_{S}\left(n_{S}+1\right)\right]}\left[T^{\max }-T\right], \\
t_{L}^{* *}(T)=T^{\max }-T .
\end{gathered}
$$

Note that $t_{S}^{* *}$ is strictly decreasing in $T$ with a slope less than $1 / 2 .{ }^{18}$ Hence, an increase in $T$ is matched by an equal reduction in the $L$ countries' local tax rate, whereas the local tax rate in each country $S$ falls by less. Therefore, the higher is $T$ the smaller is the tax gap $t_{L}^{* *}-t_{S}^{* *}$ and hence the smaller is the difference in the equilibrium levels of per capita capital [eq. (5)].

We can also show that the upper boundary of Regime II is always smaller than the maximum tax, $T_{2}<T^{\max }$. Since $t_{L}^{* *}$ is decreasing in $T$ with a slope of one and $t_{S}^{* *}\left(T^{\max }\right)=t_{S}^{*}\left(t_{L}=0\right)>0$, it follows that $t_{S}^{* *}(T)$ and $t_{L}^{* *}(T)$ must intersect at positive local tax rates in each country. ${ }^{19}$ Hence, there must exist a non-empty range of high federal taxes for which the maximum tax constraints of both types of countries are binding at the same time.

This final region is Regime $I I I$, which is comprised of federal taxes in the range

\footnotetext{
${ }^{18}$ For $n_{S}=1$, the slope of the small country's best response function (16a) would be equal to $1 / 2$. With $n_{S}>1$ the slope is reduced in absolute value, as a result of competition between several small countries.

${ }^{19}$ Note that $t_{S}^{* *}\left(T_{2}\right)=t_{L}^{* *}\left(T_{2}\right)$ by the definition of $T_{2}$. When local tax rates are positive at this point of intersection, it must be true that $T_{2}<T^{\max }$ because $t_{L}^{* *}\left(T^{\max }\right)=0$.
} 
$\left[T_{2}, T^{\max }\right]$. For any $T \geq T_{2}$, the local tax constraint becomes binding for small countries as well. Local equilibrium tax rates in all countries are then identical at the level $t_{L}^{* * *}=t_{S}^{* * *}=T^{\max }-T$, and so is the per capita capital stock in each country. At the maximum federal tax $T^{\max }$, local taxes disappear altogether and all tax revenues are generated at the federal level. Our results are summarised in:

Lemma 1 The equilibrium local taxes in each region, as a function of the federal tax rate, are characterised as follows:

$T \in\left(0, T_{1}\right)$ (Regime I): Tax rates are $\left(t_{S}^{*}, t_{L}^{*}\right)$, with interior solutions in countries $L$ and $S$. Tax rates in all countries are the same as in the one tier model of capital taxation [eq. (10)].

$T \in\left(T_{1}, T_{2}\right)$ (Regime II): Tax rates are $\left[t_{S}^{* *}=t_{S}^{*}\left(T^{\max }-T\right), t_{L}^{* *}=T^{\max }-T\right]$, with interior solutions in $S$ countries and a boundary solution in $L$ countries [eqs. (16a)(16b)]. The tax difference $t_{L}^{* *}-t_{S}^{* *}$ is falling in $T$.

$T \in\left(T_{2}, T^{\max }\right)$ (Regime $\left.I I I\right):$ Tax rates are $\left[t_{S}^{* * *}=T^{\max }-T, t_{L}^{* * *}=T^{\max }-T\right]$, with boundary solutions in $L$ and $S$. Local tax rates in all countries are identical.

\subsection{Stage 1: Choosing the federal tax rate}

We can now analyse which level of the federal tax rate $T$ will be chosen by the large and the small countries. For this we need to explore each country's total revenues for varying levels of the federal tax.

The analysis of Regime I is straightforward. Since local equilibrium taxes remain unchanged over this range, the capital allocation must remain the same as in the one tier Nash equilibrium. Hence, for each country type $j$, the effect of increasing $T$ on its overall per capita tax revenue $R_{j}^{I} \equiv T \bar{k}+t_{j}^{*} k_{j}^{*}\left(t_{j}, t_{m}\right)$ is simply

$$
\frac{d R_{j}^{I}}{d T}=\bar{k}>0 \quad \forall j .
$$

Consequently, all countries unambiguously welcome an increase in $T$ towards the interval boundary, $T_{1}$.

The analysis of Regime II is more challenging. Now, the maximum-tax constraint binds for the large countries so that these countries respond to an increase in $T$ with a one-toone reduction of their local tax $t_{L}$. Conversely, the small countries remain unconstrained 
in this range. By responding aggressively and reducing $t_{S}$ in $T$ at a rate of one, those countries could make sure that the capital allocation remains the same as in Regime I. However, as we have seen above, this is not in their best interest: each country $S$ will opt to reduce $t_{S}$ at a smaller rate [see eq. (16a)]. As a consequence, an increase in $T$ causes small countries to lose capital to the large countries. Formally, per capita tax revenues respond by ${ }^{20}$

$$
\frac{d R_{j}^{I I}}{d T}=\bar{k}+\left[t_{j} \frac{d k_{j}^{*}}{d t_{j}}+k_{j}^{*}\right] \frac{d t_{j}^{* *}}{d T}+t_{j} \frac{d k_{j}^{*}}{d t_{m}} \frac{d t_{m}^{* *}}{d T} \quad \forall j \neq m .
$$

For the large countries $j=L$, this change in revenue is certainly positive. Not only do large countries benefit directly from the increase in federal tax revenues, but they also gain from the softened tax policy of the smaller countries. We denote the slope of the small countries' best response functions in this region by $d t_{S}^{* *} / d t_{L}=c<1$ [see (16a)] and use $d t_{L}^{* *} / d T=-1$ from (16b). Moreover, since all countries of the same type choose the same tax policy, using (5) and (8) gives $d k_{L}^{*} / d t_{S}=n_{S} \alpha_{S} /(b N)=$ $-d k_{L}^{*} / d t_{L}=-n_{S} \alpha_{S} /(b N)$. Hence we obtain

$$
\frac{d R_{L}^{I I}}{d T}=\bar{k}-k_{L}^{*}+\frac{t_{L} n_{S} \alpha_{S}}{b N}(1-c)>0
$$

which is positive because $k_{L}^{*}<\bar{k}$ and $c<1$.

For a small country, there are two countervailing effects at work. On the one hand, a larger $T$ raises its federal tax revenue. At the same time, each small country not only lowers its local tax rate but it also loses part of its capital to its larger rivals. Note that the envelope theorem can be applied for small countries, so that the second term on the right-hand side of (18) is now zero. Furthermore using $d t_{L}^{* *} / d T=-1$ and $d k_{S}^{*} / d t_{S}=-d k_{S}^{*} / d t_{L}$ from (5) and (8), we obtain

$$
\frac{d R_{S}^{I I}}{d T}=\bar{k}+t_{S}^{* *} \frac{d k^{*}}{d t_{S}}=\bar{k}-k_{S}^{*}<0
$$

where the second step has once again used the first-order condition for the optimal (interior) tax rates $t_{S}^{* *}$. Since $k_{S}^{*}>\bar{k}$, equation (19b) shows that tax revenues in the small countries unambiguously fall throughout Regime II when the federal tax rate $T$ is increased. This implies that the interests of the large and small countries are directly opposed in Regime II.

\footnotetext{
${ }^{20}$ Notice that, for $L$ countries, the envelope theorem cannot be applied in the second term on the right-hand side of (18), because the large countries' tax rate is exogenously constrained.
} 
Figure 1: Tax revenues in the large and small countries for different levels of $T$

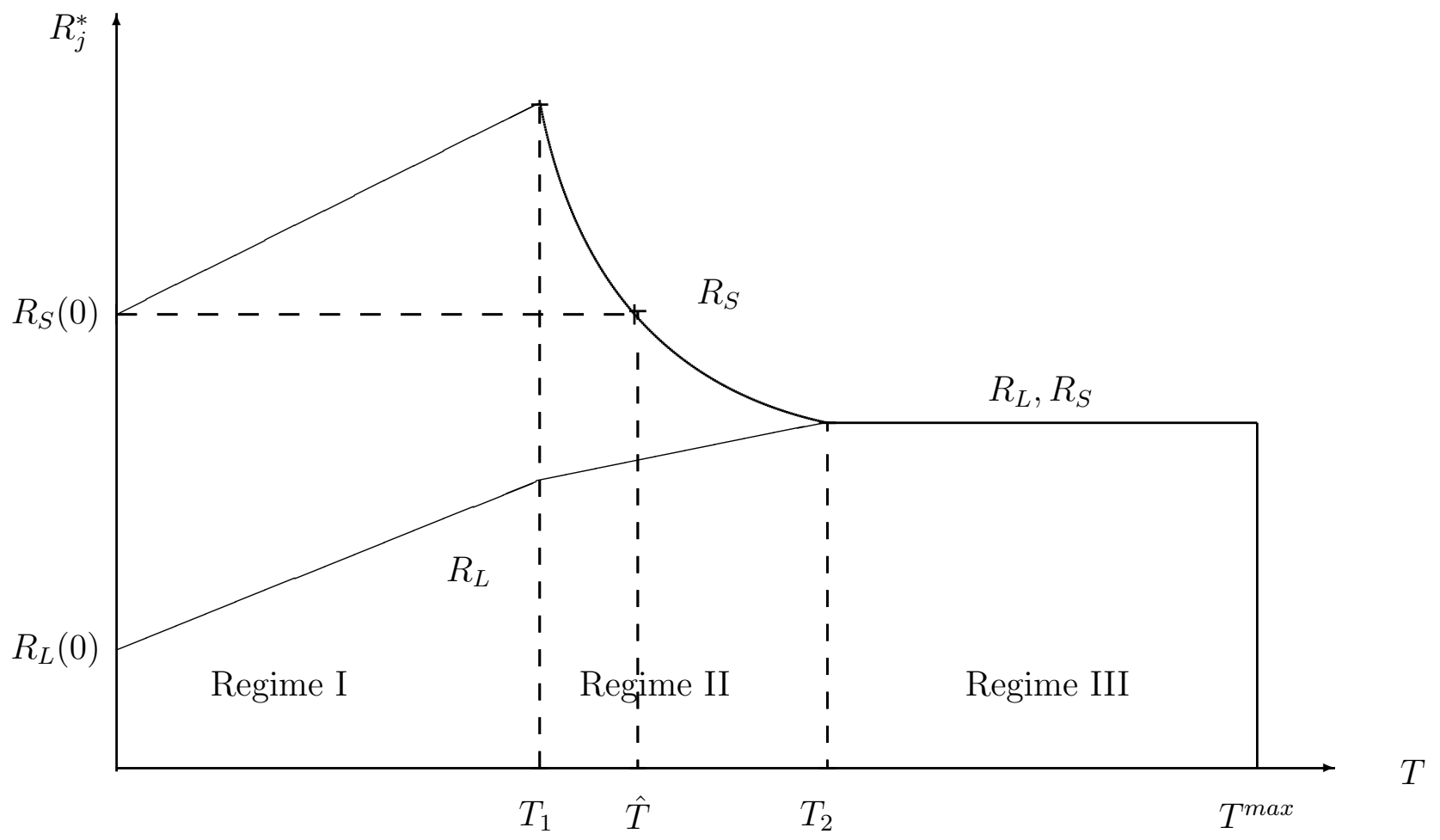

Finally, for all federal tax levels across Regime III, the allocation of capital between countries is symmetric, and total unit taxes are at their maximum. Accordingly, revenues for all countries are invariant in $T$, and are identical to those under a cooperative solution with the federal tax rate $T^{\max }$.

Figure 1 illustrates how the per capita tax revenues of the large and the small countries evolve in the different regimes. The starting point is $T=0$, where per capita tax receipts in each small country exceed those in the large countries (cf. Proposition 1). In Regime I (for $T<T_{1}$ ), tax revenues are increasing in $T$ in all countries [eq. (17)]. In Regime II (for $T_{1}<T_{2}$ ), the interests between the large and the small countries are conflicting, as $R_{L}$ is increasing in $T$ in this region, whereas $R_{S}$ is decreasing [eqs. (19a)(19b)]. Moreover, note that condition (13) implies that $R_{S}\left(T_{2}\right)<R_{S}(0)$, as the small countries gain from purely local tax competition without a federal tax. This implicitly defines a level of the federal tax $\hat{T}<T_{2}$ within Regime II, where $R_{S}(\hat{T})=R_{S}(0)$. Finally, in Regime III, per capita tax revenues are equal in all countries and reach a minimum for the small countries, but a maximum for the large countries. 
It is then obvious that the mutually agreed upon federal tax rate $T$ must lie in Regime 2 and, more specifically, within the range $\left[T_{1}, \hat{T}\right]$. The reason is that all federal tax rates below $T_{1}$ are inefficient, in the sense that revenues in all countries could be increased by raising $T$ to $T_{1}$. On the other hand, the small countries will lose from any $T>\hat{T}$, relative to a situation with a federal tax rate $T=0$, and hence will object such a choice in the absence of side payments.

Which particular federal tax $T^{*} \in\left[T_{1}, \hat{T}\right]$ is agreed upon depends on the bargaining position of the two groups of countries. Under Nash bargaining, the initial agreement specifies a $T^{*}(\gamma)$ that maximises the generalised Nash product

$$
\Delta(T)=\left\{R_{S}\left[t_{S}(T), t_{L}(T)\right]-R_{S}(0)\right\}^{\gamma}\left\{R_{L}\left[t_{S}(T), t_{L}(T)\right]-R_{L}(0)\right\}^{1-\gamma},
$$

where $R_{j}(0)$ is country $j$ 's revenue under local tax competition with no federal tax. The first-order condition $d \Delta(T) / d T=0$ yields

$$
\frac{\gamma}{1-\gamma} \frac{\left[-d R_{S}(T) / d T\right]}{\left[d R_{L}(T) / d T\right]}=\frac{R_{S}(T)-R_{S}(0)}{R_{L}(T)-R_{L}(0)}
$$

Note from (19a)-(19b) that the left-hand side of (20) is constant in $T$ and increasing in $\gamma$. Since the right-hand side is decreasing in $T$ throughout the relevant range $\left[T_{1}, \hat{T}\right]$, the solution $T^{*}(\gamma)$ is unambiguously decreasing in the small countries' bargaining parameter $\gamma$. Hence the higher is $\gamma$, the closer is the federal tax to the level $T_{1}$ at which the small countries' tax revenues are maximised.

Our results are summarised in:

Proposition 2 With dual tier capital taxation, countries will agree on a federal tax $T^{*} \in\left[T_{1}, \hat{T}\right)$, where the small countries' tax revenues at $\hat{T}$ equal those in the absence of a federal tax. In this coordinated equilibrium the following holds:

a) Tax revenues in all countries are higher than in the tax competition equilibrium without a federal tax.

b) The local capital tax equilibrium remains asymmetric with $t_{S}<t_{L}$ and $k_{S}>k_{L}$, but each country $L$ attracts a larger share of capital relative to one tier tax competition.

c) The negotiated federal tax $T^{*}$ strictly decreases in $\gamma$, the bargaining strength parameter of small countries. The higher is $\gamma$, the larger is the local tax gap $\left(t_{L}-t_{S}\right)$, and the more asymmetric is the allocation of capital. 
Proposition 2 conveys that even if side payments are (politically or otherwise) infeasible, large and small countries find it attractive to agree on a cooperatively set federal tax. We also characterise the range of potential taxes. Specifically, $T$ must be set sufficiently high to have a restraining effect on the local tax choices made by large countries, who set the larger capital taxes in a fully decentralised system. Even with cooperation, local equilibrium taxes will be asymmetric in a dual tier system, and so will be the allocation of capital. Specifics depend on the relative amount of bargaining power of the two country types. If the small countries have a sufficient bargaining strength, the federal tax is relatively small, and the positive local tax gap between large and small countries remains sizable. Conversely, if large countries are in a dominant bargaining position, negotiations yield higher federal taxes and local tax rates are more closely aligned.

\section{Discussion and Extensions}

In this section we discuss the robustness of our results. We first show that the case for a dual tier capital tax structure extends to situations in which countries can make monetary side payments to one another (Section 4.1), or settings with international capital flows to third countries (Section 4.2). We then discuss the timing of federal and local tax decisions (Section 4.3) and the allocation of the federal tax revenue (Section $4.4)$.

\subsection{Costly side payments}

As a first extension of our benchmark model, one can envision a scenario where monetary side payments from one country to the other are feasible but costly. As we have discussed in the introduction, these costs may represent political costs to the negotiating governments because voters resist monetary inter-regional side payments in exchange for political concessions. In a different interpretation, determining the level of side payments may involve costly delays of policy reform (Harstad, 2007).

Hence, we assume a dual tier structure where side payments can be made to the small countries in exchange for their willingness to agree to a federal tax rate $T$, but these side payments involve a shadow cost of $\lambda$ per unit of transfer from the large countries. To 
simplify further (and without qualitative effect), we assign all the bargaining power to the large countries $L$. In this scenario, side payments from $L$ to $S$ compensate the small countries for their loss from a federal tax rate larger than $\hat{T}$, the rate that they would just find acceptable in the absence of side payments. These payments are described as $\phi(T)=\max \left\{R_{S}(\hat{T})-R_{S}(T), 0\right\}$. The negotiated federal tax $T^{*}$ maximises total tax revenues in the union net of shadow costs, i.e., $n_{L} \alpha_{L} R_{L}(T)+n_{S} \alpha_{S} R_{S}(T)-n_{S} \alpha_{S} \lambda \phi(T)$. Notice that the solution must imply $T^{*} \geq \hat{T}$ because for smaller federal taxes the revenues of small countries exceed $R_{S}(\hat{T})$ by construction, and $\phi(T)=0$. Moreover, the optimisation yields a maximiser $T^{*}$, which in case of an interior solution $T^{*} \in\left[\hat{T}, T_{2}\right]$ satisfies

$$
n_{L} \alpha_{L} \frac{d R_{L}(T)}{d T}=-n_{S} \alpha_{S}(1+\lambda) \frac{d R_{S}(T)}{d T} .
$$

In words, the optimal $T$ is found at a point where the marginal revenue increases for large countries balance the marginal revenue losses for the small countries, weighted with the shadow costs of public funds. Note that an interior solution does not always exist: since total revenues $n_{L} \alpha_{L} R_{L}(T)+n_{S} \alpha_{S} R_{S}(T)$ strictly increase across Regime II, a corner solution with $T^{*}=\hat{T}$ and $\phi(T)=0$ prevails if shadow costs $\lambda$ are sufficiently high, i.e. if side payments are very costly. Conversely, when shadow costs are absent $(\lambda=0)$, tax revenues become fully transferable across countries and the federal tax rate is chosen so as to maximise total tax revenues in the union. The bargaining solution $T^{*}$ must then satisfy $t_{j}+T=T^{\max }$ for all countries $j=L, S$ and, as discussed in the previous section, this is achieved with any $T \geq T_{2}$. Since total tax revenues in each country remain unchanged once $T$ exceeds $T_{2}$, the equilibrium is not unique in this special case and the outcome of negotiations is found arbitrarily as $T^{*} \in\left[T_{2}, T^{\max }\right]$.

For the leading case of all intermediate shadow costs, which support an interior solution $T^{*} \in\left[\hat{T}, T_{2}\right]$, equation (21) suggests a unique $T^{*}$ which is strictly decreasing in $\lambda$. As shadow costs $\lambda$ become very high, the equilibrium level of the federal tax approaches $\hat{T}$. Conversely, as $\lambda$ falls, the solution converges to $T_{2}$.

We summarise these results in:

Proposition 3 Assume that side payments are feasible but subject to political shadow costs $\lambda$. Then the following holds:

a) For strictly positive levels of $\lambda$, there is a unique bargaining solution that satisfies $T^{*} \in\left[\hat{T}, T_{2}\right)$, with $T^{*}$ decreasing in $\lambda$. The capital allocation across countries remains asymmetric and total government revenues are not maximised. 
b) For $\lambda=0$, the outcome of negotiations is an arbitrary federal tax $T^{*} \in\left[T_{2}, T^{\text {max }}\right]$, along with properly chosen side payments to small countries. Hence, negotiations yield an efficient outcome.

Proposition 3 shows that monetary side payments from large to small countries as part of a negotiated solution facilitate a more efficient outcome. When shadow costs are absent, total tax revenues are maximised and tax revenues in all countries become completely symmetric. Positive shadow costs lead to a bargaining solution with a smaller federal tax, in order to reduce the need for monetary compensation. The outcome in this case is not fully efficient and the capital allocation remains asymmetric. However, as long as the shadow costs of side payments are not too large, the federal tax rate, and hence aggregate tax revenues, will still exceed $\hat{T}$, the highest possible federal tax in the absence of side payments (see Proposition 2).

Intuition may suggest that in a world where side payments are feasible, a dual tier capital tax system is not really needed to direct a more efficient use of resources, and to maximise government revenue objectives. As our analysis has shown, this intuition is correct only when the political shadow costs associated with monetary side payments are negligible (Proposition 3b). In this case the bargaining solution entails symmetric taxes and hence a symmetric allocation of capital across countries. This outcome can easily be replicated with a single, federal tax, set at the level $T^{\max }$, and side payments identical to those in a dual tier system.

However, a dual tier system remains strictly superior to a one tier federal tax when political shadow costs are more pronounced. In this case the bargaining solution in Proposition 3a calls for a federal tax level that does not completely eliminate local taxes. The asymmetric tax burden between large and small countries persists under the second-best solution, which is incompatible with a uniform federal tax. Intuitively, permitting countries to set asymmetric local taxes under a dual tier structure reduces the size of monetary side payments, and thus saves on the total shadow cost $\lambda \phi(T)$ incurred by the union.

\subsection{Capital flows to third countries}

In our benchmark analysis, we have captured tax competition between the union and the rest of the world in a stylised way, by imposing an upper bound $T^{\max }$ on the 
aggregate federal and local tax rate. We now extend the model to explicitly incorporate tax competition with a third country that is not a member of the union.

For simplicity, we normalise the total world population to unity and assume that there is only one large and one small country in the union, with shares $\alpha_{L}$ and $\alpha_{S}$ in the world population. The population share in the rest of the world, country $W$, is thus given by $\alpha_{W}=1-\alpha_{L}-\alpha_{S}$. The production function and the per capita capital endowment in country $W$ are the same as in the union. Hence the condition for capital market clearing [cf. eq. (2)] is now

$$
\alpha_{L} k_{L}+\alpha_{S} k_{S}+\alpha_{W} k_{W}=\bar{k}, \quad \alpha_{L}+\alpha_{S}+\alpha_{W}=1 .
$$

Capital is assumed to be imperfectly mobile between the union and the rest of the world, with mobility costs given by $\tau=(\delta / \varepsilon)\left(k_{W}-\bar{k}\right)^{\varepsilon}$, where $\delta>0$ is a cost parameter and $\varepsilon>1$. Capital mobility within the union remains perfect. For convenience, we keep capital taxation in country $W$ exogenous, and realistically assume net capital inflows from the union. Using the quadratic specification of production, the arbitrage condition for capital owners (3) under a dual tier tax structure in the union then extends to

$$
b k_{W}+\delta\left(k_{W}-\bar{k}\right)^{\varepsilon-1}=b k_{L}+t_{L}+T=b k_{S}+t_{S}+T .
$$

Finally, we assume that the federal government in the union can only tax the capital stock that remains in countries $L$ and $S$. From (22), the per capita capital base of the federal tax is then $\left(\bar{k}-\alpha_{W} k_{W}\right) /\left(\alpha_{L}+\alpha_{S}\right) \cdot{ }^{21}$

Table 2 collects the results of some representative simulations carried out in this threecountry model. Our benchmark specification is given in row (1). We consider a scenario where country $L$ is seven times larger than country $S$ and the union of countries $L$ and $S$ comprises only a relatively small share of the world population (8\%). With this specification, the gains from asymmetric tax competition for country $S$ are so large that this country refuses any uniform coordinated tax rate $t \leq 1$. Hence, the fundamental condition (13) underlying our analysis is met.

In contrast, a dual tax structure will benefit both countries. Columns (a)-(b) in Table 2 give the one tier local tax rates for countries $L$ and $S$ in the absence of a federal tax. Column (c) gives the federal tax rate $T_{1}$, for which the small country's total per capita

\footnotetext{
${ }^{21}$ Note that this per capita tax base will just equal $\bar{k}$ when there are no capital flows between the union and country $W$, i.e., when $k_{W}=\bar{k}$.
} 
Table 2: Simulation results for the three-country model

\begin{tabular}{|c|c|c|c|c|c|c|c|c|c|c|c|}
\hline & $\alpha_{L}$ & $\alpha_{S}$ & $\delta$ & $\varepsilon$ & $\begin{array}{c}(\mathrm{a}) \\
t_{L}(0) \\
\end{array}$ & $\begin{array}{c}\text { (b) } \\
t_{S}(0) \\
\end{array}$ & $\begin{array}{l}(\mathrm{c}) \\
T_{1} \\
\end{array}$ & $\begin{array}{c}(\mathrm{d}) \\
t_{L}\left(T_{1}\right) \\
\end{array}$ & $\begin{array}{c}(\mathrm{e}) \\
t_{S}\left(T_{1}\right) \\
\end{array}$ & $\begin{array}{c}(\mathrm{f}) \\
\Delta R_{L}\end{array}$ & $\begin{array}{c}(\mathrm{g}) \\
\Delta R_{S} \\
\end{array}$ \\
\hline (1) & 0.07 & 0.01 & 3.50 & 1.50 & 0.51 & 0.31 & 0.11 & 0.48 & 0.29 & $15.9 \%$ & $0.5 \%$ \\
\hline$(2)$ & 0.07 & 0.01 & 3.75 & 1.50 & 0.51 & 0.31 & 0.20 & 0.47 & 0.29 & $23.0 \%$ & $1.6 \%$ \\
\hline (3) & 0.07 & 0.01 & 3.50 & 1.45 & 0.52 & 0.32 & 0.23 & 0.47 & 0.29 & $33.0 \%$ & $2.4 \%$ \\
\hline (4) & 0.077 & 0.011 & 3.50 & 1.50 & 0.51 & 0.31 & 0.18 & 0.47 & 0.29 & $25.7 \%$ & $1.3 \%$ \\
\hline (5) & 0.069 & 0.011 & 3.50 & 1.50 & 0.47 & 0.29 & 0.24 & 0.42 & 0.26 & $34.4 \%$ & $2.8 \%$ \\
\hline
\end{tabular}

Note: Parameters held constant: $b=0.02, \bar{k}=5$.

tax revenues are maximised (see Figure 1). ${ }^{22}$ Columns (d)-(e) show the second tier local tax rates at this level of $T_{1}$. In the benchmark case of row (1), the total capital tax rate $T+t_{j}$ thus rises from $51 \%$ to $59 \%$ [the sum of columns (c) and (d)] for country $L$, and from $31 \%$ to $40 \%$ [columns (c) and (e)] for country $S .{ }^{23}$ At the same time, the equilibrium tax differential falls under the dual tier tax system. Finally, columns (f)(g) give the percentage increase in total per capita tax revenues under the optimised dual tier tax structure, in comparison to the one tier system with purely local tax competition. This per capita tax increase is always more substantial for country $L$, because the larger country gains from both the higher aggregate tax rate and the reduced intra-union tax differential.

The benchmark specification is then modified along several lines. Rows (2) and (3) show that the federal tax rate rises, and larger tax revenue gains can be secured, if capital mobility to the third country falls (i.e., if $\delta$ rises), or if the elasticity of capital flows to country $W$ is reduced ( $\varepsilon$ falls). ${ }^{24}$ Row (4) indicates that, for any given parameterisation

\footnotetext{
${ }^{22}$ Hence this federal tax would be chosen if country $S$ held all the bargaining power within the union. Note that, in contrast to Figure 1, tax revenues in $L$ will also eventually fall in the federal tax rate $T$ when the union-wide capital tax base is endogenised. However, country $S$ 's tax revenue always starts to fall at a lower federal tax so that $T_{1}$ has the same interpretation as in Figure 1.

${ }^{23}$ The high optimal tax rates in Table 2 are caused by our simplifying assumption of tax revenue maximization. Tax rates would be lower, with no changes in qualitative results, if governments maximised the utility of the representative consumer and the marginal rate of substitution between private and public consumption were constant (see footnote 11).

${ }^{24}$ Implicitly differentiating (23) shows that $\partial k_{W} / \partial \varepsilon>0$ when $0<\left(k_{W}-\bar{k}\right)<1$ in equilibrium. The latter holds in our simulations, because $\alpha_{W}$ is large [see eq. (22)].
} 
of mobility costs, the revenue gains for the union are larger when the total size of the union $\left(\alpha_{L}+\alpha_{S}\right)$ rises vis-à-vis the third country. Finally, in row (5) the size differential between the large and the small country is reduced while the total size of the union $\left(\alpha_{L}+\alpha_{S}\right)$ is held constant. In line with intuition, this increased symmetry raises the benefits for both the large and the small country. Specifically, the small country starts out from lesser per capita tax revenues, and hence has more to gain from the dual tax structure.

\subsection{Timing of federal and local tax decisions}

The timing of decisions is important to our arguments. To see this, suppose that in contrast to the above analysis, local tax rates are the long term strategic decision, which means that they are set before the federal tax is agreed upon. Suppose $\left(t_{L}, t_{S}\right)$ has been chosen in stage 1 and local governments negotiate the federal tax $T$ in stage 2 . Regardless of the choices made in stage 1, all countries now have a common interest to set $T$ to the maximum admissible level, $T=T^{\max }-\hat{t}$ with $\hat{t}=\max \left\{t_{S}, t_{L}\right\}$. The reason is that in this setting $T$ neither affects local taxes nor the capital allocation across countries. Instead, the federal tax only determines the total tax burden of investors. Hence, all countries wish to implement a federal tax as large as possible.

But this coherence of ex-post preferences has important implications for the tax equilibrium in stage 1. Specifically, large countries lose their interest to choose relatively high local taxes. Suppose the equilibrium in stage 1 satisfies $t_{i}>t_{h}$ for countries $i, h$. Then, country $i$ would like to lower its taxes (at least) to $t_{h}$ : since $T=T^{\text {max }}-t_{i}$ in this range, lowering $t_{i}$ leaves country $i$ 's aggregate tax $t_{i}+T$ unaffected, while at the same time raising country $i$ 's capital endowment.

By the same token, raising $t_{i}$ in a symmetric situation with $t_{i}=t_{h}$ cannot benefit country $i$, because its own capital allocation shrinks while its total tax rate $t_{i}+T$ remains constant. As these arguments show, only symmetric tax rates can potentially be sustained in equilibrium. And, in fact, a combination of identical local tax rates $t_{L}=t_{S}=0$ forms an equilibrium. ${ }^{25}$

\footnotetext{
${ }^{25}$ In addition, any combination of identical taxes $t_{L}=t_{S}$ forms an equilibrium, which is small enough (in particular, sufficiently smaller than $t_{S}^{*}$ ) so that $S$ countries do not find it beneficial to undercut $t_{L}$.
} 
In a dual tier scenario in which countries move first and federal taxes are set subsequently, the capital allocation would thus be symmetric and the outcome of a one tier federal taxation would be replicated. Clearly, small countries would not find such a regime agreeable if they oppose uniform taxes (or a one tier federal tax) in the first place. Hence, for a dual tier tax structure to have an effect, federal taxes must be designed as long run, strategic choices. This, however, can also be expected in most policy settings, in part because the need for negotiations over the federal tax rate would serve as a commitment not to change this tax rate frequently.

\subsection{Allocation of federal tax revenue}

Finally, we discuss the assumption in our baseline model that federal tax revenue is redistributed on a per capita basis or, equivalently, in proportion to capital endowments. As a possible alternative, suppose now that spending is proportional to the equilibrium level of capital employed in each country, corresponding to a source-based distribution of the federal tax. Per capita tax revenues for each country type $j$ then become $R_{j}=\left(t_{j}+T\right) k_{j}^{*}\left(t_{j}, t_{m}\right)$. In this scenario, federal taxes are completely neutral and cease to have any effect on either capital allocation or equilibrium tax revenues. To see this, note that replacing a country's strategic tax variable $t_{j}$ by the new variable $\tilde{t}_{j}=t_{j}-T$, it is obvious that the new equilibrium in local taxes satisfies $\tilde{t}_{j}^{*}=t_{j}^{*}-T$. Intuitively, countries can undo the federal tax in stage 2 , so that the overall economic results are the same as in the absence of such a tax.

This argument must be modified, however, when taxes are subject to a non-negativity constraint. Note first that small federal taxes $T$ do not constrain any country's ability to set its preferred local tax rate (Regime I), but substantial federal taxes do. Since $\tilde{t}_{S}^{*}<\tilde{t}_{L}^{*}$, the non-negativity constraint first becomes binding for small countries (Regime II). These countries will then set the boundary $\operatorname{tax} \tilde{t}_{S}^{*}=0$, which reduces the tax gap between large and small countries. Union-wide tax revenues increase in $T$ while the revenues of small countries shrink. ${ }^{26}$ With an even larger $T$, the constraint $t_{L} \geq 0$ becomes binding for large countries as well (Regime III). Only federal taxes are now levied, and all local revenues naturally increase in $T$ to the point where $T=T^{\max }$.

\footnotetext{
${ }^{26}$ The reasoning is thus very similar to Section 3.2 [eq. (19b)]. However, the reduced tax gap now results from the fact that the tax rate of the small countries is constrained from below, whereas in our benchmark model the tax rate of the large countries was constrained from above.
} 
In this scenario, small countries will not agree on a federal tax if our initial condition (13) holds. This is because, in contrast to the base model, tax revenues of the small countries do not increase in Regime I, and they fall in Regime II as a result of the non-negativity constraint. Clearly, designing a two-tier system in this way is of no help, in contrast to a system that distributes federal tax revenues in proportion to capital endowments, that is, on an equal per capita basis.

\section{Conclusions}

Our paper has started out from an empirically relevant scenario where asymmetric countries within a federation compete for mobile capital. Decentralised taxation yields inefficiently low equilibrium tax rates, but small countries may nevertheless benefit from tax competition by undercutting their larger neighbours and attracting capital from them. Hence, small countries will resist a reform towards capital tax harmonisation, even if the latter increases aggregate tax revenues within the union.

We propose a two tier tax structure to mitigate this problem. Under this scheme, the asymmetric member states of a union choose a common, federal tax rate in the first stage, and then non-cooperatively set local tax rates in the second stage. We show that this mechanism effectively reduces tax competition between the members of the union, without completely eliminating tax differences. At the same time, the dual tax structure ensures that the gains from partial coordination are distributed across the federation members in a way that yields a strict Pareto improvement over a one tier system of decentralised capital tax competition. Moreover, as the tax gap between small and large countries narrows, the marginal products of capital are also more closely aligned in equilibrium, improving production efficiency within the union. Finally, we have shown that these advantages of a dual tax structure extend to settings in which costly side payments between countries are feasible, and where capital flows to the rest of the world are allowed.

The results of our analysis have direct policy implications for federations that maintain strong taxing powers of its individual member states, such as the European Union. A critical insight of our model is that the European Union should not attempt a complete tax harmonisation, which may be politically infeasible because of its adverse effects on small countries. Rather, the Union may want to introduce an additional EU-wide 
corporation tax and use the proceeds to reduce the contributions of member states in relation to each country's capital endowment. In the case of the European Union, a good proxy for this would be to reduce the GDP-based contributions of each member state to the Community budget. Using an established channel to redistribute the additional tax receipts will also help to limit the possible inefficiencies that may arise from political lobbying for the additional funds

Our model can be extended in several directions. A first possible extension is to account for capital tax evasion, and for the fact that different schemes of capital taxation may also affect the efficiency of tax administration. Hence a tax effort variable could be incorporated into the model, linking the decision on how strictly the capital tax is enforced to the direct gains that the respective jurisdiction has from tighter enforcement. These incentives have been studied in the fiscal federalism literature in the context of fiscal equalisation schemes (e.g. Bucovetsky and Smart, 2006; Buettner, 2006) and similar issues might be relevant under the dual tax scheme discussed here. A second issue is to account for heterogeneity in the preferences of countries, in addition to differences in population size. This would imply that the tax rates set in an autarky equilibrium would differ among the members of the union. We would expect that this changes the distribution of the gains from a dual tier capital tax structure, but leaves our qualitative conclusions intact. We leave a detailed analysis of these extensions to future research. 


\section{References}

Alesina, A., Angeloni, I., Etro, F. (2005). International unions. American Economic Review 95, 602-615.

Barba Navaretti, G., Venables, A. (2004). Multinational Firms in the World Economy. Princeton University Press.

Besley, T., Coate, S. (2003). Centralized versus decentralized provision of local public goods: A political economy analysis. Journal of Public Economics 87, 2611-2637.

Bettendorf, L., Devereux, M.P., van der Horst, A., Loretz, S., de Mooij, R. (2010). Corporate tax harmonization in the EU. Economic Policy 63, 537-590.

Bucovetsky, S. (1991). Asymmetric tax competition. Journal of Urban Economics 30, 167-181.

Bucovetsky, S., Smart, M. (2006). The efficiency consequences of local revenue equalization: tax competition and tax distortions. Journal of Public Economic Theory 8, 119-144.

Buettner, T. (2006). The incentive effects of fiscal equalization transfers on tax policy. Journal of Public Economics 90, 477-497.

Cassette, A., Paty, S. (2008). Tax competition among Eastern and Western European countries: with whom do countries compete? Economic Systems 32, 307-325.

Conconi, P., Perroni, C., Riezman, R. (2008). Is partial tax harmonization desirable? Journal of Public Economics 92, 254-267.

Davies, R., Voget, J. (2011). Tax competition in an expanding European Union. GEE Paper No. 33. Portuguese Ministry of Economics, Lisbon.

Devereux, M.P., Lockwood, B., Redoano, M. (2008). Do countries compete over corporate tax rates? Journal of Public Economics 92, 1210-1235.

European Commission (2011). Proposal for a Council Directive on a Common Consolidated Corporate Tax Base (CCCTB). Document COM (2011) 121/4. Brussels. 
Grubert, H., Mutti, J. (2000). Do taxes influence where U.S. corporations invest? National Tax Journal 53, 825-839.

Harstad, B. (2007). Harmonisation and side payments in political cooperation. American Economic Review 97, 871-889.

Haufler, A., Wooton, I. (2006). The effects of regional tax and subsidy coordination on foreign direct investment. European Economic Review 50, 285-305.

Hindriks, J., Peralta, S., Weber, S. (2008). Competing in taxes and investment under fiscal equalization. Journal of Public Economics 92, 2392-2402.

Janeba, E., Wilson, J.D. (2011). Optimal fiscal federalism in the presence of tax competition. Journal of Public Economics 95, 1302-1311.

Kanbur, R., Keen, M. (1993). Jeux sans frontières: Tax competition and tax coordination when countries differ in size. American Economic Review 83, 877-892.

Keen, M. (1993). The welfare economics of tax co-ordination in the European Community: A survey. Fiscal Studies 14, 15-36.

Keen, M. (2001). Preferential regimes can make tax competition less harmful. National Tax Journal 54, 757-762.

Keen, M., Kotsogiannis, C. (2002). Does federalism lead to excessively high taxes? American Economic Review 92, 363-370.

Keen, M., Smith, S. (1996). The future of value added tax in the European Union. Economic Policy 23, 375-420.

Kessler, A., Lülfesmann, C., Myers, G.M. (2002). Redistribution, fiscal competition and the politics of economic integration. Review of Economic Studies 69, 899-923.

Konrad, K. (2009). Non-binding minimum tax rates may foster tax competition. Economics Letters 102, 109-111.

Konrad. K., Schjelderup, G. (1999). Fortress building in global tax competition. Journal of Urban Economics 46, 156-167.

Köthenbürger, M. (2002). Tax competition and fiscal equalization. International Tax and Public Finance 9, 391-408. 
Lockwood, B. (2002). Distributive politics and the costs of centralization. Review of Economic Studies 69, 313-337.

Nicodème, G. (2009). On recent developments in fighting harmful tax practices. $N a$ tional Tax Journal 62, 755-771.

Oates, W. (1972). Fiscal Federalism. Harcourt Brace Jovanovich, New York.

OECD (2011). Revenue Statistics 1965-2010. www.sourceoecd.org

Romalis, J. (2007). Capital taxes, trade costs, and the Irish miracle. Journal of the European Economic Association 5, 459-469.

Ruding Committee (1992). Report of the committee of independent experts on company taxation. Brussels and Luxembourg.

Sørensen, P.B. (2004). International tax coordination: regionalism versus globalism. Journal of Public Economics 88, 1187-1214.

Wang, Y.-Q. (1999). Commodity taxes under fiscal competition: Stackelberg equilibrium and optimality. American Economic Review 89, 974-981.

Wildasin, D. (2011). Fiscal competition for imperfectly-mobile labor and capital. A comparative dynamic analysis. Journal of Public Economics 95, 1312-1321.

Wilson, J.D. (1991). Tax competition with interregional differences in factor endowments. Regional Science and Urban Economics 21, 423-451.

Wrede, M. (2000). Shared tax sources and public expenditure. International Tax and Public Finance 7, 163-175. 